\title{
Anti-inflammatory and Cytotoxic Activities of Five Veronica Species
}

\author{
U. Sebnem Harput, ${ }^{a, b}$ Iclal Saracoglu, ${ }^{b}$ Makoto Inoue, ${ }^{*}, a$ and Yukio Ogihara ${ }^{a}$ \\ Laboratory of Pharmacognosy, Graduate School of Pharmaceutical Sciences, Nagoya City University, ${ }^{a}$ 3-1 Tanabe-dori, \\ Mizuho-ku, Nagoya 467-8603, Japan and Department of Pharmacognosy, Faculty of Pharmacy, Hacettepe University, ${ }^{b}$ \\ TR-06100 Ankara, Turkey. Received November 26, 2001; accepted December 13, 2001
}

\begin{abstract}
Biological activities of five Veronica species (Scrophulariaceae), V. cymbalaria, V. hederifolia, V. pectinata var. glandulosa, $V$. persica and $V$. polita were studied for their anti-inflammatory and cytotoxic activities. Their methanol extracts showed both the inhibitory activity of nitric oxide (NO) production in lipopolysaccharide (LPS)-stimulated macrophages and cytotoxic activity against KB epidermoid carcinoma and B16 melanoma. When the methanol extracts were fractionated between water and chloroform, water fractions significantly inhibited NO production without any cytotoxicity, while chloroform fractions showed cytotoxicity dose-dependently. When the radical scavenging activity was determined using 2,2-diphenyl-1-picryl-hydrazyl (DPPH), water fractions of the five Veronica species scavenged free radicals effectively, suggesting that the inhibitory effect of this species on NO production was due to their radical scavenging activity. On the other hand, chloroform fractions of Veronica species except for $V$. cymbalaria showed similar cytotoxic activity against KB and B16 melanoma cells.
\end{abstract}

Key words Veronica species; Scrophulariaceae; nitric oxide; macrophages; cytotoxicity; 2,2-diphenyl-1-picryl-hydrazyl (DPPH)

In the flora of Turkey, the genus Veronica L. (Scrophulariaceae) is represented by 79 species, 26 of which are endemic. ${ }^{1}$ In traditional Turkish medicines, some Veronica species are used as diuretics and in the healing of wound. ${ }^{2)}$ In addition, several Veronica species are used to treat cancer, influenza, hemoptysis, leryngopharyngitis, hernia, cough and respiratory diseases and are also used as an expectorant and antiscorbutic. $^{3-5)}$ Veronica species contain mainly iridoid glucosides, especially benzoic and cinnamic acid esters of catalpol, some phenylethanoid and flavonoid glycosides. ${ }^{6-11)}$ However, there is no report on the action mechanism of this genus.

In our continuous research on Turkish medicinal plants, we have tried to evaluate the biological and pharmacological activity of Veronica species using a bioassay-guided fractionation method. In the present study, focusing on anti-inflammatory and cytotoxic activities, we screened five Veronica species. Suppressive effects on nitric oxide (NO) production in lipopolysaccharide (LPS)-stimulated macrophages were used to evaluate anti-inflammatory activity. Activated macrophages produce large amounts of important effector molecules that elicit inflammation. NO, a bioactive free radical, is one of these critical mediators which is produced by inducible NO synthase (iNOS) in inflammatory macrophages when stimulated with bacterial membrane components, LPS and cytokines. ${ }^{12)}$ Although many studies have demonstrated that cytokine-induced NO production can damage parasites or tumor cells, NO is also linked to damage and death of normal cells. ${ }^{13)}$ In fact, higher NO levels are demonstrated in patients with rheumatoid arthritis, systemic lupus erythematosous and inflammatory myositis, indicating that NO elicits and aggravates inflammation. ${ }^{14)}$ The inflammatory effect of NO is mediated by its ability as a free radical and is associated with the increase in iNOS expression. Therefore, the suppressive effect on NO production in LPS stimulated macrophages is one of the useful indexes for evaluating antiinflammatory activity. The level of iNOS expression and the free radical scavenging ability mainly regulates NO level. In the present study, we assessed the anti-inflammatory effect of Veronica species by determining NO levels, iNOS expression and radical scavenging activity. Radical scavenging activity was evaluated using the 2,2-diphenyl-1-picryl-hydrazyl (DPPH) free radical scavenging system. In this assay, antioxidants react with the stable free radical DPPH (which gives a strong absorption at $517 \mathrm{~nm}$ ), resulting on the production of colorless 2,2-diphenyl-1-picryl hydrazine. ${ }^{15)}$

In addition, to find a novel activity of Veronica species, the cytotoxicity after treatment of tumor cells (KB and B16) with test fractions was determined using microculture tetrazolium assay. ${ }^{16)}$

\section{MATERIALS AND METHODS}

Reagents LPS (from Escherichia coli) and 3-(4,5-dimethylthiazol-2-yl)-2,5-diphenyl tetrazolium bromide (MTT) were purchased from Sigma (St. Louis, MO, U.S.A.). Thioglycollate (TG) broth was obtained from DIFCO (Detroit, MI, U.S.A.). DPPH was purchased from Aldrich Chem. Co. (Milw., WI, U.S.A.). Dimethyl sulfoxide (DMSO), 2-mercaptoethanol, 3-tert-butyl-4-hydroxyanisole (BHA), dl- $\alpha$-tocopherol were obtained from Nacalai Tesque Co. (Kyoto, Japan).

Plant Materials Aerial parts of the five Veronica species were collected from different places in Turkey and identified as V. polita Fries, V. persica PoIRET, V. hederifolia L. V. pectinata L. var. glandulosa Riek ex M.A., and V. cymbalaria BoDARD. Voucher specimens have been deposited in the herbarium of Faculty of Pharmacy, Hacettepe University (HUEF 99013, 99015, 99016, 99014, 99131).

Preparation of Herb Extracts and Fractions The airdried aerial parts of the plants (V. polita, $598 \mathrm{~g} ; V$. persica, $220 \mathrm{~g}$; V. hederifolia, $275 \mathrm{~g}$; V. pectinata var. glandulosa, $80 \mathrm{~g} ;$ V. cymbalaria, $27 \mathrm{~g}$ ) were extracted twice with $\mathrm{MeOH}$ at $40{ }^{\circ} \mathrm{C}$ for $12 \mathrm{~h}$. The $\mathrm{MeOH}$ solutions were evaporated under vacuum to give $\mathrm{MeOH}$ extracts (yield: V. polita, $90 \mathrm{~g}$; V. persica, $35 \mathrm{~g}$; V. hederifolia, $40 \mathrm{~g}$; V. pectinata var. glandu- 
losa, $16 \mathrm{~g} ;$ V. cymbalaria, $6 \mathrm{~g})$. MeOH extracts were dissolved in water and fractionated to afford the $\mathrm{CHCl}_{3}$ and water soluble portions. All the above fractions were tested for in vitro anti-inflammatory activity and cytotoxicity. All tested extracts and fractions were dissolved in DMSO on the day of the experiment and appropriately diluted with medium. Final concentration of DMSO never exceeded $0.5 \%(\mathrm{v} / \mathrm{v})$. The control group received only vehicle containing the same concentration of DMSO.

Animals, Cell Lines and Cell Culture Media Male ICR mice at 6 weeks of age were obtained from Charles River Japan and used between $7-10$ weeks of age. KB (human epidermoid carcinoma) and B16 (mouse melanoma) cells were provided by the Health Science Research Resources Bank (Sennan, Osaka). Fetal calf serum (FCS), RPMI 1640 medium and minimal essential medium (MEM)Eagle's salts (with non-essential amino acids) were obtained from Irvine Scientific Co. (Santa Ana, CA, U.S.A.). Antibiotics (penicillin and streptomycin) were purchased from Life Technologies Inc. (Grand Island, NY, U.S.A). Mouse peritoneal macrophages, $\mathrm{KB}$ and $\mathrm{B} 16$ cells were cultured in RPMI 1640 medium containing 2-mercaptoethanol and MEM-Eagle's salts medium supplemented with $10 \%$ FCS, $100 \mathrm{U} / \mathrm{ml}$ penicillin and $100 \mu \mathrm{g} / \mathrm{ml}$ streptomycin, respectively.

Macrophage Culture Macrophages were harvested by peritoneal lavage using cold RPMI 1640 medium without FCS $4 \mathrm{~d}$ after intra-peritoneal injection of $2.5 \mathrm{ml}$ of $3 \% \mathrm{TG}$. Macrophages $\left(2 \times 10^{6}\right.$ cells $\left./ \mathrm{ml}\right)$ were incubated for $2 \mathrm{~h}$ in 96 multi-well plates in $5 \% \mathrm{CO}_{2}$ in air; and then non-adherent cells were removed by washing with fresh medium. Remaining adherent cells were cultured in RPMI 1640 medium with $10 \%$ FCS containing various concentrations of test samples with or without $10 \mu \mathrm{g} / \mathrm{ml}$ LPS for $22 \mathrm{~h}^{17}{ }^{17}$

Measurement of Nitrite Concentration To measure $\mathrm{NO}_{2}{ }^{-}$derived from $\mathrm{NO}$ in culture medium, $100 \mu \mathrm{l}$ of culture supernatants was mixed with $100 \mu \mathrm{l}$ of Griess reagent $(1 \%$ sulfanilamide, $0.1 \%$ naphthylethylenediamine dihydrochloride, $2.5 \% \mathrm{H}_{3} \mathrm{PO}_{4}$ ). After chromofore was formed at room temperature for $10 \mathrm{~min}$, absorbance at $577 \mathrm{~nm}$ was determined using a microplate reader (Model 450, Bio-Rad). $\mathrm{NO}_{2}{ }^{-}$concentration was determined using sodium nitrite as a standard. ${ }^{18)}$

DPPH Free Radical Scavenging Activity The free radical scavenging effect of the extracts was assessed by the decoloration of a methanol solution of DPPH according to Hatano et al. $^{15)}$ In this assay, the degree of the decoloration indicates the free radical scavenging efficiency of the substances. Briefly, EtOH solution $(500 \mu \mathrm{l})$ of test compounds at various concentrations was added to an EtOH solution $(500 \mu \mathrm{l})$ of $\mathrm{DPPH}(100 \mu \mathrm{M})$. The reaction mixture was shaken vigorously and then kept at room temperature for $30 \mathrm{~min}$. The absorbance of the remaining DPPH was measured in $1 \mathrm{~cm}$ cuvettes using a Shimadzu UV-240 spectrophotometer at $520 \mathrm{~nm}$ and the radical-scavenging activity was determined by comparing the absorbance with that of a blank $(100 \%)$ containing only DPPH and solvent. BHA and $d l-\alpha-$ tocopherol were used as standards and the samples were prepared using the same dilution procedures.

In Vitro Cytotoxicity Assay One tenth milliliter cell suspensions of KB and B16 cells were seeded into 96-multi- well plates at a concentration of $6 \times 10^{4}$ cells $/ \mathrm{ml}$ and cultured for $24 \mathrm{~h}$. Cells were incubated with various concentrations of the test fractions in a humidified $5 \% \mathrm{CO}_{2}$ incubator at $37^{\circ} \mathrm{C}$ for $48 \mathrm{~h}$. After incubation, the cells were washed and replaced by fresh medium. Ten microliters of MTT solution $(10 \mathrm{mg} / \mathrm{ml}$ in phosphate buffered saline (PBS)) was added and incubation followed for $4 \mathrm{~h}$. Following the incubation, $100 \mu \mathrm{l}$ of $10 \%$ sodium dodecyl sulfate (SDS, $100 \mu \mathrm{l}$ ) was added to each well to dissolve the formed formazan. The absorbance was measured at $577 / 655 \mathrm{~nm}$ using the microplate reader. ${ }^{16)}$

\section{RESULTS}

Effect of the MeOH Extracts and Their Fractions of Veronica Species on NO Synthesis in Mouse Peritoneal Macrophages To investigate the anti-inflammatory effect of Veronica species, we examined the effect of $\mathrm{MeOH}$ extracts on NO synthesis in vitro. TG-elicited mouse peritoneal macrophages were incubated with five $\mathrm{MeOH}$ extracts at a concentration of $200 \mu \mathrm{g} / \mathrm{ml}$ in the presence of $10 \mu \mathrm{g} / \mathrm{ml}$ of LPS. We found that all $\mathrm{MeOH}$ extracts showed inhibitory activity on NO production, whereas they did not show any effect on NO production in the absence of LPS (Fig. 1). During the course of the experiment, viability of the macrophages was not altered in the presence or absence of the fractions as determined by MTT assay (data not shown). When these $\mathrm{MeOH}$ extracts were fractionated between water and $\mathrm{CHCl}_{3}$, the inhibitory activity on NO production was recovered in the water soluble portions. It was found that the water soluble portions were more effective than $\mathrm{MeOH}$ extracts, and that the water soluble portion of $V$. hederifolia exhibited the most potent activity among the tested Veronica species (Fig. 2). Since the $\mathrm{CHCl}_{3}$ soluble portions showed significant cytotoxicity against macrophages, we were not able to determine the activity on NO synthesis.

DPPH Free Radical Scavenging Activity To examine the basis of the inhibitory activity on NO production, free radical scavenging activity of the water soluble portion of five $\mathrm{MeOH}$ extracts was assessed by the decoloration of a methanol solution of DPPH. As shown in Table 1, all five Veronica species markedly stimulated the decoloration at a

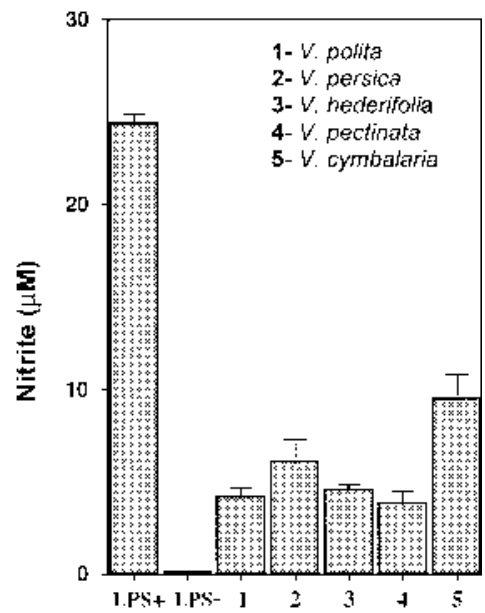

Fig. 1. Inhibition of NO Production by Five MeOH Extracts

Cells $\left(2 \times 10^{6}\right.$ cells $\left./ \mathrm{ml}\right)$ were incubated for $22 \mathrm{~h}$ with $100 \mu \mathrm{g} / \mathrm{ml}$ of the extracts in the presence of LPS $(10 \mu \mathrm{g} / \mathrm{ml})$. After incubation, $\mathrm{NO}_{2}{ }^{-}$concentration was determined by the Griess method 
concentration of $200 \mu \mathrm{g} / \mathrm{ml}$. Their $\mathrm{IC}_{50}$ values were as follows: V. polita $14.1 \mu \mathrm{g} / \mathrm{ml} ;$ V. persica $34.0 \mu \mathrm{g} / \mathrm{ml}$; V. hederifolia $74.3 \mu \mathrm{g} / \mathrm{ml} ; V$. pectinata var. glandulosa $40.5 \mu \mathrm{g} / \mathrm{ml} ; V$. cymbalaria $61.8 \mu \mathrm{g} / \mathrm{ml}$. BHA and $d l-\alpha$-tocopherol effectively suppressed the decoloration under the same conditions and their $\mathrm{IC}_{50}$ values were found to be 12.3 and $10.0 \mu \mathrm{g} / \mathrm{ml}$, respectively.

Cytotoxic Activity All MeOH extracts showed cytotoxicity against $\mathrm{KB}$ and B16 cells, dose dependently (Fig. 3). In addition, their chloroform soluble portions exhibited more

Table 1. DPPH Radical Scavenging Activity of Water Fractions of Five Veronica Species, $d l-\alpha$-Tocopherol and BHA

\begin{tabular}{|c|c|c|c|c|}
\hline & \multicolumn{3}{|c|}{$\%$ DPPH decoloration } & \multirow{2}{*}{$\frac{\mathrm{IC}_{50}}{(\mu \mathrm{g} / \mathrm{ml})}$} \\
\hline & $200 \mu \mathrm{g} / \mathrm{ml}$ & $100 \mu \mathrm{g} / \mathrm{ml}$ & $25 \mu \mathrm{g} / \mathrm{ml}$ & \\
\hline$V$ polita & 95 & 90 & 60 & 14.1 \\
\hline V.persica & 91 & 89 & 37 & 34.0 \\
\hline V. hederifolia & 88 & 67 & 21 & 74.3 \\
\hline V. pectinata var. glandulosa & 90 & 87 & 37 & 40.5 \\
\hline V. cymbalaria & 85 & 81 & 24 & 61.8 \\
\hline BHA & 94 & 88 & 73 & 12.3 \\
\hline$d l-\alpha$-Tocopherol & 95 & 89 & 80 & 10.0 \\
\hline
\end{tabular}

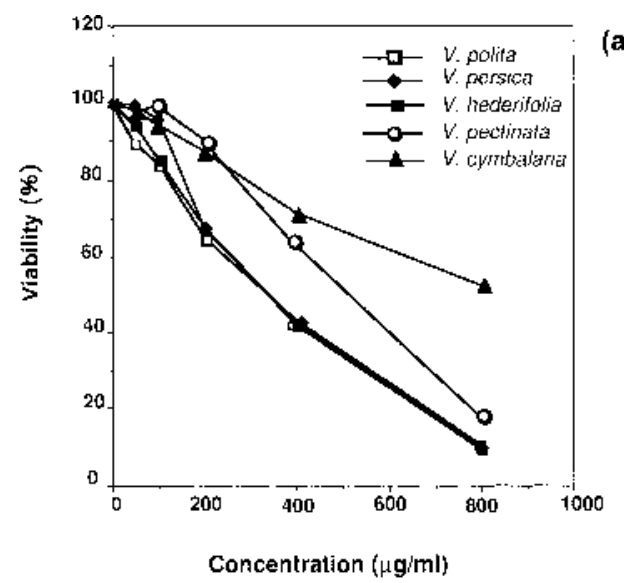

potent cytotoxicity than $\mathrm{MeOH}$ extracts (Fig. 4). Veronica species except for $V$. cymbalaria showed similar strong cytotoxicity against KB cells, and three Veronica species, V. per-

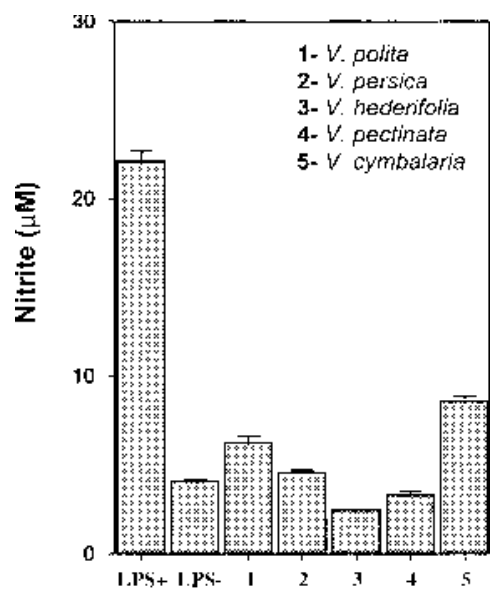

Fig. 2. Inhibition of NO Production by Water Fractions of Five MeOH Extracts

Cells $\left(2 \times 10^{6}\right.$ cells $\left./ \mathrm{ml}\right)$ were incubated for $22 \mathrm{~h}$ with $100 \mu \mathrm{g} / \mathrm{ml}$ of the fractions in the presence of LPS $(10 \mu \mathrm{g} / \mathrm{ml})$. After incubation, $\mathrm{NO}_{2}{ }^{-}$concentration was determined by the Griess method.

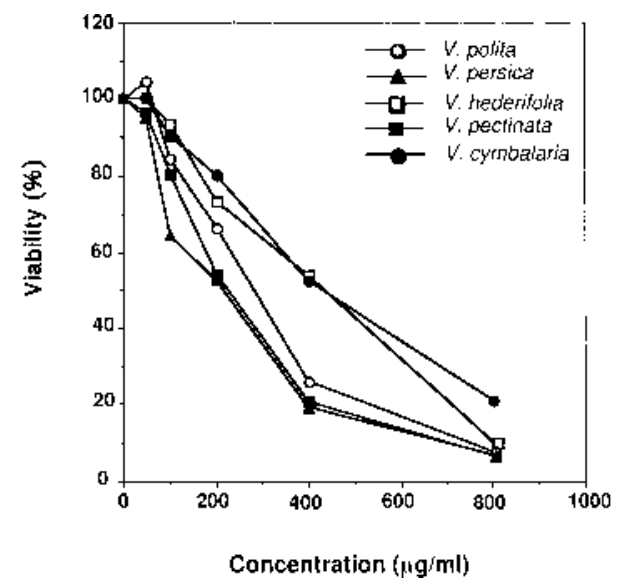

(b)

Fig. 3. Cytotoxic Effects of Five MeOH Extracts on (a) KB and (b) B16 Cells

Cells $\left(6 \times 10^{4}\right.$ cells $\left./ \mathrm{ml}\right)$ were incubated for $48 \mathrm{~h}$ with various concentrations of the extracts. After incubation, viability was determined by the MTT method. Each value represents the mean \pm S.E. of 8 wells.
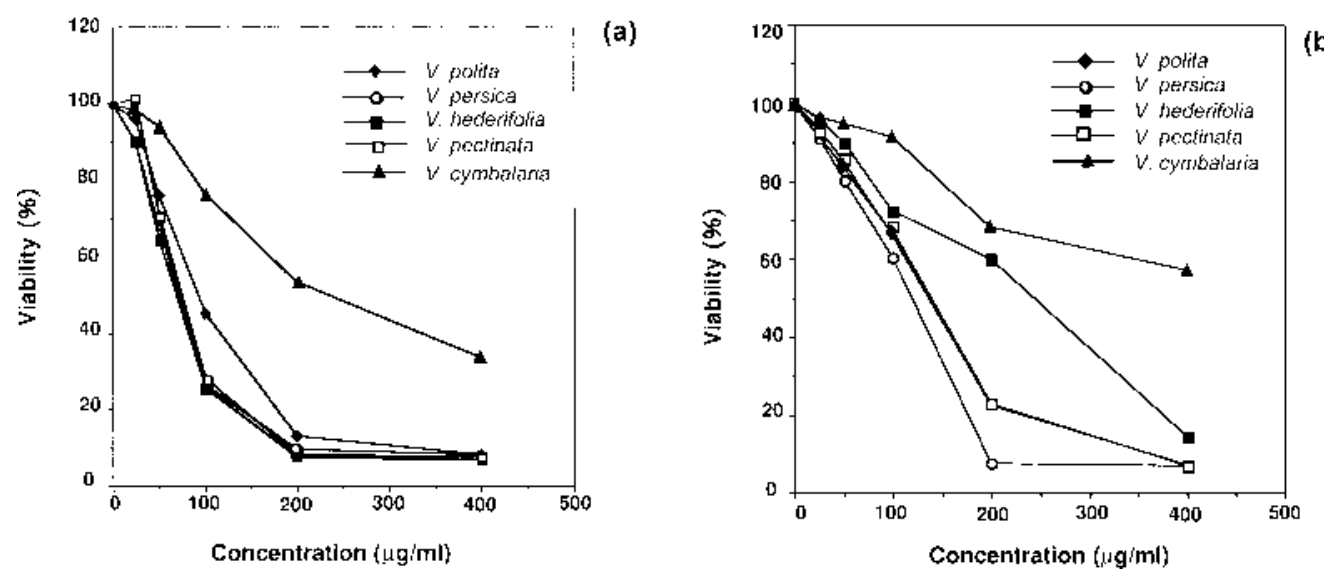

(b)

Fig. 4. Cytotoxic Effects of $\mathrm{CHCl}_{3}$ Fractions of Five MeOH Extracts on (a) $\mathrm{KB}$ and (b) B16 Cells

Cells $\left(6 \times 10^{4} \mathrm{cells} / \mathrm{ml}\right)$ were incubated for $48 \mathrm{~h}$ at various concentrations of the fractions. After incubation, viability was determined by the MTT method. Each value represents the mean \pm S.E. of 8 wells. 
sica, V. polita, V. pectinata var. glandulosa, exhibited potent activity against B16 cells. However, the water soluble portions did not show any cytotoxicity.

\section{DISCUSSION}

Although Veronica species have been widely used in oriental medicine for inflammatory diseases, the pharmacological effects of these species have not been fully investigated. Therefore, in the present study five Veronica species were evaluated for their inhibitory effect on NO production in mouse peritoneal macrophages and cytotoxic activity against two tumor cell lines, KB and B16 cells. Our results demonstrated that the $\mathrm{MeOH}$ extracts of these five species possessed anti-inflammatory and cytotoxic activities. Further fractionation separated anti-inflammatory and cytotoxic activities into water and chloroform soluble fractions, respectively.

NO is enzymatically produced from arginine and oxygen by three distinct nitric oxide synthase (NOS) isozymes which include two constitutively transcribed forms, neutral (nNOS) and endothelial (eNOS) enzymes and an inducible enzyme (iNOS) in a number of cell types, including macrophages. ${ }^{12)}$ When the mechanism underlying NO inhibition by Veronica species was examined, the expression of iNOS protein was not altered between control and the water soluble portion of Veronica species. This indicated that the inhibition of NO production by Veronica species was not due to a suppressive effect on transcription or translation. Then, to determine whether the inhibition of NO production is correlated with radical scavenging activity of the extract, the radical scavenging activity of water fractions was evaluated using the DPPH free radical scavenging assay. Water fractions of the five Veronica species caused marked decoloration at $100 \mu \mathrm{g} / \mathrm{ml}$, indicating that their radical scavenging activities are comparable to that of BHA and $d l-\alpha$-tocopherol which are wellknown antioxidants. Therefore, these findings suggest that the suppressive effect of Veronica species on NO production is, in part, due to their scavenging activity of NO produced by macrophages, and this scavenging effect may result from the presence of a high content of phenolic compounds such as flavonoids and phenylethanoids.

When stimulated with LPS or interleukin, macrophages produce not only NO but also other oxygen radicals such as the superoxide anion radical and the hydroxyl radical. NO can also react with superoxide anion to form an even stronger oxidant peroxynitrite $\left(\mathrm{ONOO}^{-}\right)$. At the level of the whole organism, reactive peroxynitrite might be considered beneficial because of its cytotoxicity to bacteria or other invading organisms. However, excessive production of peroxynitrite would damage normal tissue. ${ }^{19)}$ This is why the protection of normal tissue from peroxynitrite is important in the process of inflammation. Thus, regulation of NO synthesis by Veronica species may have therapeutic benefits in a patient with inflammation accompanied by autoimmune disease or infection.

In the present study, we also found that the five Veronica species showed cytotoxic activity, and further fractionation indicated that the active compounds existed in the most nonpolar fraction but not in other fractions. In addition, $\mathrm{KB}$ cells were more sensitive to the $\mathrm{CHCl}_{3}$ soluble portions of the extracts than B16 cells. Cytotoxic compounds have never been isolated from Veronica species to date. Further work to isolate active constituents, to determine their structures and to clarify their mode of action is currently under way. However, our findings in the present study give us new insight into an explanation of the usage of Veronica species in traditional Turkish medicines.

Acknowledgement The authors are grateful to Prof. Dr. Z. Aytac of Gazi University, Faculty of Sciences, Ankara, Turkey for the authentication of the plant specimens.

\section{REFERENCES}

1) Davis P. H., "Flora of Turkey and The East Aegean Islands," Vol. 6, University Press, Edinburgh, 1978, pp. 689-753.

2) Baytop T., Therapy with Medicinal Plants in Turkey (Past and Present), Publications of Istanbul University, No: 3255, Istanbul, 1984, p. 423.

3) Tomassini L., Brkic D., Serafini M., Nicoletti M., Fitoterapia, 66, 382 (1995).

4) Su B., Zhu Q., Jia Z., Tetrahedron Lett., 40, 357-358 (1999).

5) Graham J. G., J. Ethnopharmacol., 73, 347-377 (2000).

6) Chari V. M., Grayer-Barkmeijer R. J., Harborne J. B., Osterdahl B. G., Phytochemistry, 20, 1977-1979 (1981).

7) Lahloub M. F., Zaghloul M. G., Afifi M. S., Sticher O., Phytochemistry, 33, 401— 405 (1993).

8) Aoshima H., Miyase T., Ueno A., Phytochemistry, 37, 547-550 (1994).

9) Taskova R., Handjieva N., Peev D., Popov S., Phytochemistry, 49, 1323-1327 (1998).

10) Ozipek M., Saracoglu I., Kojima K., Ogihara Y., Calis I., Chem. Pharm. Bull., 47, 561-562 (1999).

11) Taskova R., Handjieva N., Evstatieva L., Popov S., Phytochemistry, 52, 1443-1445 (1999).

12) Knowles G. R., Moncada S., Biochem. J., 298, 249-258 (1994).

13) Moncada S., Palmer R. M., Higgs E. A., Pharmacol. Rev., 43, 109 142 (1997).

14) Wanchu A., Khullar M., Sud A., Bambery P., Biology and Chemistry, 3, 454-458 (1999).

15) Hatano T., Edamatsu R., Hiramatsu M., Mori A., Fujita Y., Yasuhara T., Okuda T., Chem. Pharm. Bull., 37, 2016-2021 (1989).

16) Mosmann T., J. Immunological Methods, 65, 55-63 (1983).

17) Inoue M., Shen Y. R., Ogihara Y., Biol. Pharm. Bull., 19, 1468-1473 (1996).

18) Green L. C., Wagner D. A., Glogowski J., Skipper P. L., Wishnok J. S., Tannenbaum S. R., Anal. Biochem., 126, 131-138 (1992).

19) Lewis C. E., McGee J. O’D., "The Macrophage: The Natural Immune System," Oxford University Press, 1992 